\title{
Asiantunteva ja eettinen teos ohjauksesta ja neuvonnasta
}

Jussi Onnismaa (2007). Ohjaus- ja neuvontatyö. Aikaa, huomiota ja kunnioitusta. Gaudeamus. 207 sivua.

Tämä kirja perehdyttää lukijan ohjauksen lähtökohtiin ja tuo uusia näkökulmia myös kokeneille ohjaajille. Kirja esittelee viime vuosien keskustelua ohjaustyön muuttumisesta ja sen mahdollisuuksista. Onnismaa tarkastelee myös kriittisesti tämän ajan ilmiöitä ohjauksen ja neuvonnan näkökulmasta. Työelämän ennakoimattomuus, jatkuva muutos ja kiire ovat johtaneet uusiin ohjauksen ja neuvonnan lähestymistapoihin. Kirja keskittyy erityisesti työelämän ohjaukseen ja kutsuu eri tahoja yhteiseen vuoropuheluun.

Kirja on rakenteeltaan tiivis ja tarjoaa mielenkiintoista luettavaa. Lähdeviitteistö on runsas ja monipuolinen. Ohjaukseen ja neuvontaan liittyvät käsitteet on määritelty selkeästi. Käsitteestä ohjattava tulee tosin mieleen näkemys passiivisesta toimenpiteiden kohteena olevasta ihmisestä. Hyvä, että Onnismaa määrittelee asiakkaana olevan ohjattavan aktiiviseksi toimijaksi ja oman elämänsä asiantuntijaksi. Aiheisiin liittyvät teoriat ja historialliset katsaukset ovat sujuvasti luettavassa muodossa muun tekstin joukossa.

Ammatillisen keskustelun muotona ohjaus on määritelty kirjassa laaja-alaiseksi elämänsuunnittelun menetelmäksi, jota voidaan soveltaa monissa eri ammateissa. Ohjauksen tavoitteena on auttaa ohjattavaa elämään aiempaa tasapainoisemmin ympäristönsä kanssa sekä käyttämään omia mahdollisuuksiaan tavoitteellisesti hyväkseen. Ohjaus on usein yhteistyötä, elämänsuunnittelun riskikysymysten ja eettisten kysymysten yhteistä tarkastelua, arviointia sekä merkitysten etsintää.

Kirjassa käydään huolella läpi, miten ja missä ohjataan ja neuvotaan, millaisin taidoin sitä tehdään sekä millaisia tavoitteita oppilaitokset ovat opintoohjaukselle asettaneet. Aluksi keskitytään erityisesti ohjaajan ja ohjattavan väliseen vuorovaikutukseen, käytettäviin työvälineisiin sekä ohjattavalle annettavaan ajan, huomion ja kunnioituksen antamiseen.

Lyhyen historiallisen katsauksen valossa tarkastellaan alussa ohjaustyön kehittymistä puhtaasta uraohjauksesta yleiseksi elämänsuunnittelun menetelmäksi.

Tiedottamisessa asiakas etsii puuttuvaa tietoa, jolloin hän on tiedon vastaanottaja ja työntekijä on tiedon antaja. Neuvonnassa asiakas odottaa saavansa ongelmaan neuvoja asiantuntijalta. Ohjauksessa ohjattava osallistuu aktiivisesti esittämiensä ongelmien ratkaisemiseen. Ohjauskeskustelussa pyritään vahvistamaan ohjattavan toimintakykyä ja vähentämään valmiiden ratkaisumallien tarjoamista. Asiakaslähtöisessä suuntauksessa ohjaaja pyrkii tulemaan toimeen mahdollisimman vähin perustiedoin, koska tärkein tieto on ohjattavalla itsellään.

\section{Viesti ajasta, huomiosta ja kunnioituksesta}

Nykypäivän korostuneesti kiireisissä organisaatioissa ei valitettavasti tueta pitkäjänteistä ohjaustyötä. Riittämättömyyden tunne voi vaivata sekä ohjaajaa että ohjattavia. Siksi tämän kirjan viesti ajan, huomion ja kunnioituksen korostamisesta on ensiarvoisen tärkeä.

Ohjauksella voidaan parhaimmillaan tukea aikuista ristiriitaisissa tilanteissa. Sillä voidaan paikata työelämän murroskohdissa syntynyttä arvokkuusvajetta sekä riittämättömyyden tunnetta.

Toisessa luvussa keskitytään 
ohjattavan kielenkäytöön, kuinka ohjattava puhuu, millaista todellisuutta ja millaisia kertomuksia hän tulkinnoillaan tuottaa ja mahdollistaa. Ohjauksen kieli on muuttunut. Onnismaa toteaa aiheellisesti narratiivisten ja voimavarakeskeisten menetelmien riskeistä. Ohjaaja saattaa tyrkyttää liian innokkaasti uusia näkökulmia. Tällöin niiden uskottavuus vähenee ja ohjaajan hyvää tarkoittava toiminta voi pyyhkiä ohjattavan historiaa ja kokemuksia pois.

\section{Mukautumisen vaade}

Onnismaan kriittinen näkemys elinikäiseen oppimiseen on tervetullutta. Elinikäisen oppimisen korostus vaatii jatkuvasti joustamaan sekä toistuvasti oppimaan ja mukautumaan. Länsimaisessa kulttuurissa aikuisuus oikeutetaan vain jatkuvaa uudistumista ja nuorekkuutta korostamalla. Onnismaa viittaa myös suomalaisen aikuiskoulutuksen epätasa-arvoisuuteen, joka korostaa oma-aloitteisuutta ja itseohjautuvuutta. Aktiivisen ohjaus- ja neuvontatyön avulla voisi koulutuksen ulkopuolella olevat saada osallistumaan siihen nykyistä enemmän. Työelämän ja yhteiskunnan muutokset lisäävät kuitenkin tarvetta urasuunnitteluun ja osaamisen kehittämiseen koko työuran ajan.

Kirjassa nostetaan mielenkiintoisella tavalla esiin myös nykypäivän työelämän parasdokseja. Näistä mainittakoon esimerkiksi työntekijöiden parantunut terveydentila ja toisaalta heikentynyt työntekijöiden kokema työkyky. Työelämästä puuttuu nykyisin vastavuoroisuuden periaate. Työntekijöiden keskinäinen luottamus ja lojaa- lisuus työnantajaa kohtaan vähenee, mikäli työelämän kokemusta väheksytään ja työntekijät kokevat olevansa vain "kulutustavaraa”.

\section{Ohjauksen etiikka}

Työelämäohjaus sisältää nykyisin monenlaista toimintaa organisaatiossa: työnohjausta, henkilöstökoulutusta ja -johtamista, työuraohjausta, kehittämistoimintaa, työterveystoimintaa sekä mentorointia ja kollegiaalista yhteistyötä. Ohjauksen voisi nähdä ennalta määrättyjen ohjeiden sijasta resurssina ja työvälineenä ohjausprosessin kaikissa vaiheissa. Ohjausalan ammatillisten ohjeiden pohjalta ei välttämättä voida ammattimaista toimintaa tarkastella. Onnismaan mainitsema toimintakykyetiikka tarjoaa aineksia keskusteluun ohjaustyön tarkoituksesta.

Ohjauksen ja neuvonnan vaikuttavuuden arviointi nähdään yleisesti tarpeellisena huolimatta sen ongelmallisuudesta ja kiistanalaisista kysymyksistä. Erityisen vähän on myös pohdittu arvioinnin eettisiä kysymyksiä.

\section{Mahdollisuuksien taju}

Ohjauksen asiantuntijuus on muuttunut työurien ja elämänkulun ennustamattomuuden myötä. Nykyään ohjaustyössä tarvitaan ennen kaikkea mahdollisuuksien tajua. Asiantuntijuudessa pyritään vuoropuheluun ja kuuntelemiseen sekä uusien näkökulmien löytämiseen. On pyrittävä lisäämään ihmisten omaa vastuuta elämästään. Samalla myös luomaan ja tukemaan ohjattavan sosiaalisia verkostoja. Valitettavasti uudet liikkeen- johdolliseen suuntaan vievät ohjaustavat eivät aina tarjoa eettistä pohjaa ohjaukselle ja neuvonnalle tai muulle ohjaustyölle.

Yleiseen suomalaiseen näkemykseen viitaten Onnismaa toteaa, että ohjaus- ja neuvontatyö ei ole terapiaa. Kirjassa käsitellään kuitenkin monia ohjauksen että terapian teemoja rinnakkaisina ilmiöinä. Ohjauksessa pätee sama kuin terapiassakin: hyvässä suhteessa terapeutti pystyy luomaan liittolaisuuden asiakasta auttavien voimien kanssa. Ohjauksessa ja erityyppisissä psykoterapioissa painottuvat yhä enemmän asiakkaan omat voimavarat ja näkökulman vaihdokset erilaisten vajavaisuusoletusten sijasta. Ohjauksessa ja terapiassa on Onnismaan näkemyksen mukaan myös samoja piirteitä kuin kasvatuksessa.

Tämä teos valottaa vuosituhannen vaihteen kansainvälistä ja kotimaista keskustelua ohjaus- ja neuvontatyön mahdollisuuksista, muutoksista ja sen tarpeellisuudesta. Kirja kokonaisuudessaan on selkeä, kiinnostava ja ansiokas esitys ohjausja neuvontatyön käytänteistä. Moniammatillinen yhteistyö ja verkostuminen tuovat myös ammattietiikkaan uusia pulmia, jotka vaativat jatkuvaa eettisten kysymysten pohdintaa. Kirjaa voi suositella niin ohjaus- ja neuvontatyötä kuin myös terapiatyötä tekeville.

\section{Aini Jaari}

